AMERICAN JOURNAL OF FOOD AND NUTRITION

Print: ISSN 2157-0167, Online: ISSN 2157-1317, doi:10.5251/ajfn.2011.1.3.109.113

(C) 2011, ScienceHu $\beta$, http://www.scihub.org/AJFN

\title{
Effect of chilling on microbial load of two fish species (Oreochromis niloticus and Clarias lazera)
}

\author{
Ibrahim Musa Adam Mohammed and Samia Hamid Ahmed Hamid
}

College of Science and Animal Production Technology, Sudan University of Science and Technology, Department of Fisheries and Wildlife Science

College of Science and Animal Production Technology, Sudan University of Science and Technology, Khartoum, Sudan.

\begin{abstract}
This study was conducted at the Sudan University of Science and Technology, Department of Fisheries and Wildlife Science, to identify the bacterial load on fresh and chilled fresh fish. This study was carried out on 36 fish samples, 18 Tilapia fish (Oreochromis niloticus) and 18 catfish (Clarias lazera), at the period from November 2009 to March 2010. Samples were collected from El-morada fish market and pre-chilled with ice in thermostatic container then, divided into three groups (fresh, iced and refrigerated). The first group was tested fresh, the second was tested after icing from $4-7$ days and the third tested after refrigerated from $4-7$ days. The studied samples were tested microbiologically and the results were $8.4 \times 10^{5}$ and $1.7 \times 10^{5} \mathrm{CFU} / \mathrm{gm}$ for fresh Tilapia and fresh catfish respectively. For 4 days iced samples the result was $3.2 \times 10^{5}$ and $9.3 \times 10^{5} \mathrm{CFU} / \mathrm{gm}$ for Tilapia and catfish respectively, for 7 days iced samples the result were $1.7 \times 10^{6}$ and $1.3 \times 10^{6} \mathrm{CFU} / \mathrm{gm}$ for Tilapia and catfish respectively. The result of refrigerated samples for 4 and 7 days were $2.1 \times 10^{6}$ and $1.1 \times 10^{7} \mathrm{CFU} / \mathrm{gm}$ for Tilapia and $8.8 \times 10^{6}$ and $1.6 \times 10^{7}$ $\mathrm{CFU} / \mathrm{gm}$ catfish, respectively. The results of the total bacterial count indicated that the highest contamination steps were the process that Tilapia and catfish were packed in polyethylene bags after chilled storage at $4^{\circ} \mathrm{C}$ for 7 days, and that Tilapia and catfish showed the level of contamination as $1.1 \times 10^{7}$ and $1.6 \times 10^{7}$ cfulg, respectively. Therefore, total bacterial counts results were over the standard value in TACFS 7001 - 2004 (Thai Agricultural Commodity of Food Standard). While the amount of bacterial count of Tilapia and catfish stored in ice for 7 days were $1.7 \times 10^{6}$ and $1.6 \times 10^{6}$ cfulg, respectively. Also the results showed a significant difference $(P<$ 0.05 ) between iced and refrigerated samples.
\end{abstract}

Keywords: Microbial load, chilling, fish.

\section{INTRODUCTION}

Fish are the most numerous of vertebrate, with at least 20,000 known species, and more than $58 \%$ are found in marine environment (Thurman and Webber, 1984).

In the Sudan fish is distributed over an area that amount to $100,000 \mathrm{~km}^{2}$ of fresh water and $760 \mathrm{~km}$ of marine, the total sustainable production amount to 114,100 tones/ year and human consumption is estimated at only $1.4 \mathrm{~kg} /$ year (Meske, 1985).

Fish in the Sudan have been a major source of protein and energy for many communities especially among the Nilotic tribes of the south and some of Nubian ethnic groups of the far north especially in the lean month of the year. Sudanese people use fish sometimes as the only source of animal protein throughout the years as substitute for meat, particularly in the central Nile valley.

Fish is one of the most highly perishable commodities and the public has always required continuous reassurance about its quality. Unlike most raw materials, fish is not a single commodity but consist of a large number of species of widely different sizes and shape. Because of this variety consumers are often unsure if particular species of product made from them are good to eat. Many countries now have comprehensive system of inspection and control of at least some aspects of fish quality. Thus from several points of view fish quality has become very important in the world. This is because consumers now are more aware of possible food hazards and malpractices which will affect the quality as a result of bad handling and processing. Therefore, consumers 
individually or collectively become more demand in respect of freshness, naturalness, microbial safety, free from pollutants and protection from damage.

Recently, the demand of Tilapia (Oreochromis niloticus) consumption has increased continuously because $O$. niloticus is of low price with high nutrition food. The whole fish and fillet are admirable for consumers. As a result, it affects the trend of both domestic and export consumption. Moreover, the $O$. niloticus has many outstanding advantages such as easy to culture, high growth rate, easy breeding, high fibrilla protein, good taste, white cotton meat like sea bass fish, high nutrition and having more Omega-3 than other wild freshwater fishes and wild estuarine fishes. (Aquatic Animal Research Centre Charoenpokphand, 1999).

Clarias lazera (Garmout) which was equally investigated in this study is capable of existing in muddy ponds and haffirs throughout the dry season, so it is relatively obtainable in any part of year and is more abundance after the rainy season, the specimen of Clarias lazera may exceed on hundred centimeters in length may approximately weigh 2-3 bounds (Mills, 1956).

The rate of deterioration in fish is highly temperature dependant and can be inhibited by use of low storage temperature (Sivertsvik et al., 2002). Chilling generally slowdown the deterioration of seafood. The prevalent method of retarding spoilage in India as well as in other tropical countries is storage in ice (Surrendran et al., 1989). The most common chilling medium for preserving fresh fish is ice. However, the quantity of crushed ice required for chilling fresh fish is quite substantial which is at least 1:1 ratio (wt/wt) and sometimes is even higher with tropical conditions (Lima dos Santos et al., 1981). When the atmospheric surrounding of the product is modified to reduce oxygen concentration, the shelflife is increased considerably due to the reduction in the rate of the chemical oxidation by oxygen as well as in the growth of aerobic microorganisms (Stile, 1991).

The main objectives of this work are summarized as following:

- To investigate the effect of chilling on the quality of Tilapia and catfish.

- To determine the microbial load on fresh and chilled fish.

\section{MATERIALS AND METHODS}

Collection of fish samples: Fish samples were collected using gill net and cast net. A total of 18 samples of Oreochromis niloticus and 18 samples of Clarias lazera were collected from Elmourda fish market, during November 2009 to March 2010. The samples were taken from three regions of fish muscles, these are: caudal, middle and anterior region.

Fish treatment: Thirty six samples, from18 Tilapia (Oreochromis niloticus), $120-180 \mathrm{~g}$ and 18 catfish (Clarias lazera), 300 - $1200 \mathrm{~g}$ bought from Elmourada fish market were iced in thermostatic container and transported to the Sudan University of Science and Technology, College of Veterinary Medicine and Animal Production. The fish were divided into three groups; one was put in a container and mixed with ice, ratio 1:1, layer of ice and layer of fish, 3 samples were stored for 4 days and the other 3 samples were stored for 7 days. Second group was filleted and packed in plastic bags, then placed in refrigerator, 3 samples stored for 4 days and other 3 samples were stored for 7 days. The third group was treated as fresh (control), finally the whole samples were analyzed.

Bacteriological examination: Solid media were used for bacteriological investigation.

Plate count agar: Five grams of casein enzyme hydrolysis, 2.59 of yeast extract, $1 \mathrm{~g}$ of dextrose and $9 \mathrm{~g}$ agar were dissolved in $1000 \mathrm{ml}$ distilled water. After that the medium was boiled to blend the media and the reconstituted medium was adjusted to $\mathrm{pH} 7$. Then it was sterilized by autoclaving at 15 pound per square inch pressure $\left(121^{\circ} \mathrm{C}\right)$ for 15 minutes.

\section{Bacteriological method:}

1 Preparation of the sample: The samples were homogenized in sterile mortar and put in sterile tubes.

Preparation of serial dilutions: Separate sterile pipettes were used, decimal dilution of $10^{-2}, 10^{-3}, 10^{-4}$, $10^{-5}$ and others were prepared, and sample was homogenized by transferring $1 \mathrm{ml}$ of previous dilutions to $9 \mathrm{ml}$ of diluents. Samples foam avoided, all dilution were shacked 25 times within 7 seconds. $1 \mathrm{ml}$ of each dilution was pipeted into separate duplicate, appropriately marked Petri dishes. Two plates were inoculated per dilution $15-20 \mathrm{ml}$ plate count agars were added (after cooled to $45^{\circ} \mathrm{C} \pm 1$ ) to each plate within 15 min. of original dilution (AOAC,1980). 
Total viable count (TVC): The test was done according to Guinn et al., (1999). Immediately sample dilutions and agar medium were mixed thoroughly and uniformly by alternate rotation and back and forth motion of plates on flat level surface. The poured agar let to solidify; the solidified Petri dishes were inverted and incubated promptly for $48 \pm 2$ hrs at 37 ${ }^{\circ} \mathrm{C}$. Thirty to three hundreds colonies were counted. The total colony count per milliliter was calculated by multiplication of the number of colonies counted by dilution level.

Statistical analysis:- The obtained results were analyzed statistically using factorial arrangement. The test was used to evaluate the mean differences among different treatments at the 0.05 significance level (Dowdy and Wearden, 1991; SAS, 1988).

\section{RESULTS AND DISCUSSION}

\section{Results:}

Table 1: bacterial load (cfulg) on iced fresh fish Tilapia (Oreochromis nilotics)

\begin{tabular}{|c|c|c|}
\hline Days of storage & Total viable count \pm Sd. & Range \\
\hline 0 & $8.7 \times 10^{5} \pm 7.4 \times 10^{5}$ & $1.6 \times 10^{5}-1.9 \times 10^{6}$ \\
\hline 4 & $3.2 \times 10^{5} \pm 8.5 \times 10^{4}$ & $2.4 \times 10^{5}-4.1 \times 10^{5}$ \\
\hline 7 & $1.7 \times 10^{6} \pm 6.5 \times 10^{5}$ & $1 \times 10^{6}-2.3 \times 10^{6}$ \\
\hline
\end{tabular}

$\mathrm{cfu} / \mathrm{g}=$ colony forming unitlgram

$\mathrm{Sd} .=$ standard deviation

Table 2: bacterial load (cfulg) on refrigerated fresh fish Tilapia (Oreochromis niloticus)

\begin{tabular}{|c|c|c|}
\hline Days of storage & Total viable count \pm Sd. & Range \\
\hline 0 & $8 \times 10^{5} \pm 8.5 \times 10^{5}$ & $1.8 \times 10^{5}-2 \times 10^{6}$ \\
\hline 4 & $2.1 \times 10^{6} \pm 1.2 \times 10^{6}$ & $1 \times 10^{6}-3.4 \times 10^{6}$ \\
\hline 7 & $1.1 \times 10^{7} \pm 2.6 \times 10^{6}$ & $9 \times 10^{6}-1.4 \times 10^{7}$ \\
\hline
\end{tabular}

cfu/g = colony forming unitlgram

Sd. $=$ Standard deviation

Table 3: bacterial load (cfulg) on ice fresh catfish (Clarias lazera)

\begin{tabular}{|c|c|c|}
\hline Days of storage & Total viable count \pm Sd. & Range \\
\hline 0 & $2.6 \times 10^{5} \pm 1.8 \times 10^{5}$ & $1.6 \times 10^{4}-4.8 \times 10^{5}$ \\
\hline 4 & $9.3 \times 10^{5} \pm 7.1 \times 10^{5}-1.6 \times 10^{6}$ \\
\hline 7 & $1.6 \times 10^{6} \pm 1.7 \times 10^{5}$ & $1.2 \times 10^{6}-1.5 \times 10^{6}$ \\
\hline
\end{tabular}

cfu/g = Colony forming unitlgram

Sd. $=$ standard deviation 
Am. J. Food. Nutr, 2011, 1(3): 109-113

Table 4: bacterial load (cfulg) on refrigerated fresh catfish (Clarias lazera)

\begin{tabular}{|c|c|c|}
\hline Days of storage & Total viable count \pm Sd. & Range \\
\hline 0 & $8 \times 10^{4} \pm 7.1 \times 10^{4}$ & $2.2 \times 10^{4}-1.8 \times 10^{5}$ \\
\hline 4 & $8.8 \times 10^{6} \pm 9.8 \times 10^{6}$ & $1.6 \times 10^{6}-2 \times 10^{\prime}$ \\
\hline 7 & $1.6 \times 10^{\prime} \pm 1.5 \times 10^{\prime}$ & $1.9 \times 10^{6}-3.2 \times 10^{\prime}$ \\
\hline
\end{tabular}

cfu/g = Colony forming unitlgram

Sd. = standard deviation

\section{DISCUSSIONS}

Bacterial growth is the main cause of fish spoilage; therefore it is logical to use bacterial number as an index of fish quality. In this study the total number of bacterial count for fresh Tilapia (Oreochromis niloticus) was $8.4 \times 10^{5}$ cfulg of fish meat, and this number was in the accepted limit mentioned by SSMO (Sudanese Standards and Metrology Organization, SDS 357) which was $5 \times 10^{5}-10^{6}$ cfulgm for fresh fish products. Also this number was in the normal range stated by Liston (1980) which was $10^{2}-10^{7}$ cfulg of fish meat. Also Shewan (1977) reported that the bacterial flora on freshly caught fish depends on environment rather than fish species, and this reflects the wide range of bacterial count. Also this study revealed that the total bacterial count for iced fresh Tilapia (O. nilticus) for 4 and 7 days were $3.2 \times 10^{5}$ and $1.7 \times 10^{6}$ cfulg of fish meat, respectively. This is accepted limit compared to Anon (1991) who said that the total mesophilic aerobic bacterial counts over $10^{6}$ cfulg are regarded as the acceptability limit for seafoods. The same limit is also accepted for freshwater fish (Turantas, 2000). Also the result is in agreement with Jeyasekaran et al., (2006) who reported that the initial total bacterial count was found to be $10^{5} \mathrm{cfulg}$, when the fish were chilled with ice. The total viable bacterial count of refrigerated Tilapia (O. nilticus) for 4 and 7 days were $2.1 \times 10^{6}$ and $1.1 \times 10^{7}$ cfulg of fish meat, respectively. In case of refrigerated tilpia fore 4 days it was considered in normal range of fresh as mentioned by Hoffman (1971) who stated that the bacterial count of $10^{2}-10^{7}$ cfulg of skin surface is normal range. The number of bacteria of refrigerated Tilapia for 7 days was in critical point in case of bacterial contamination as mentioned by Thai Agricultural Commodity and Food Standard (TACFS 7001, 2004) which indicated that the critical point of Tilapia in case of bacterial contamination of fish meat, the total bacterial count is not greater than $1 \times 10^{7}$ cfulg of fish meat, and it considered as critical point.
In case of catfish (Clarias lazera) the total viable count of bacteria in fresh catfish was $1.7 \times 10^{5}$ cfulg of fish meat. This was accepted number of bacteria compared to that mentioned by Anon (1991) who said that the acceptability limit is $10^{6}$ cfulg for mesophilic aerobic bacteria. Also Sikorski (1990) reported that for high quality fresh fish, the number of bacteria present on the surface vary from $10^{3}-10^{4}$ cfulg. Also this result is in agreement with Ahmed (2007) who reported that the total viable count of bacteria of fresh catfish was $3.7 \times 10^{5}$ cfulg. Also the study revealed that catfish (Clarias lazera) stored in ice for 4 and 7 days, the total viable count of bacteria were $9.3 \times 10^{5}$ and $1.6 \times 10^{6}$ cfulg of fish meat respectively. These results agree with finding of Chou (1993) who reported that the total aerobic plate count of unwashed and washed catfish frame mince without cryoprotectants were $5 \times 10^{6}$ cfulg and $10^{6}$ cfulg, respectively. The total viable count of bacteria of refrigerated catfish (C.lazera) for 4 days was $8.8 \times 10^{6}$ cfulg, is regarded in normal range of freshness as stated by Liston (1980) which was $10^{2}-10^{7}$ cfulg of fish meat, and the total viable count of refrigerated catfish for 7 days was $1.6 \times 10^{7}$ cfulg of fish meat. This is considered in critical point compared to (Olafsdottir 1997) who reported that the total viable count of fish products is $10^{7}-10^{8}$ cfulg at the point of sensory rejection.

\section{CONCLUSION}

Recently, the demand of Tilapia fish (Oreochromis niloticus) and catfish (Clarias lezera) consumption have increased continuously because, these fishes are of low price but, high nutrition food. The results of the total bacterial count indicated that the highest contamination steps were in the process that Tilapia and catfish were packed in polyethylene bags after chilled storage at $4{ }^{\circ} \mathrm{C}$ for 7 days and that Tilapia and catfish showed the level of contamination as $1.1 \times 10^{7}$ and $1.6 \times 10^{7}$ cfulg, respectively. Therefore, total bacterial counts results are over the standard value in TACFS 7001-2004. While the amount of bacterial count of Tilapia and catfish stored in ice for 7 days were $1.7 \times 10^{6}$ and $1.6 \times 10^{6}$ cfulg, respectively. 


\section{REFERENCES}

Ahmed, S. H. (2007). Effect of isolated bacteria on blood parameters and meat quality of Oreochromis niloticus. Departmentof Fisheries and Wildlife Science, College of Science and Animal Production Technology, Sudan University, Sudan (Ph.D. Thesis) 48P.

Anon, YMOUS. (1991). Su Urunlerinde Mikrobiyolojik ve Agir Metal Kabul Edilebilir Degerler. Resmi Gazete, 28 mayis 20884, p 5.

AOAC. (1980). Association of Official Analytical Chemist, Official method of Analysis. (ed. Harwitz, W.) 3ed Washington.

Aquatic Animal Research Center Charoenpokphand. (1999). Taptim fish culture, Technical Paper (Leaflet) $6 \mathrm{p}$.

Chou, C. (1993). Evaluation of Quality Changes in Frozen Catfish (Ictalurus punctatus) Mince [M.S. thesis]. Baton Rouge, La.: Louisiana State University.

Dowdy, S. and Wearden, S. (1991). Statistics for Research. 2nd ed. New York: John Wiley \& Sons. p 629.

Giunn, P. J. Cartner, M. E., Makey, B. K. and Cartner, G. R. (1999). Clinical Veterinary Microbiology, Virginia, U. S. A.

Hoffman, G. (1971). Methods for diagnosis of fish diseases. American Publishing Co- PUT- HD.

Jeyasekaran, G., Ganesan, P., Anandraj, R. and Jeya shakila, R. (2006). Effect of pre-chilling on the shelflife and quality of Silver pomfret (Pampus argenteus) stored in dry and wet ice. Department of Fish processing Technology, Fisheries College and Research Institute, Tamilnadu Veterinary and Animal Science University, Tuticorin 628 008, India, P 117 128.

Lima dos Santos, C. A. M. (1981). The storage life of tropical fish in ice. A review Trop. Sci. 23: $97-127$.

Lima dos Santos, C. A. M., D. James and F. Teutscher. (1981). Guidelines for chilled fish storage Experiment. FAO Fisheries Technical Paper No. 210: $17-22$.

Liston, D. (1980). Microbiology in fishery science in advances in Fishes Science Technology ( $\mathrm{e}-\mathrm{d}$ by $\mathrm{j}-\mathrm{j}$ - connel), pp. 183 - 57- Fishing New books Itd, Farnham.

Liston, J. (1980). Microbiology in fishery science. In: Connell $\mathrm{JJ}$, editor. Advances in Fish Science and Technology. Farnham, Surrey, U.K.: Fishing News Books. p 138 - 157.

Meske, C. (1985). Fish Aquaculture Technology and Federal Research Center for Fisheries, Institute for
Costal and Inland Fisheries, Hamburg, Federal Republic of Germany. Edited and translated by Fredrick Vogt. Formally of the polytechnic of Central London, U. K.

Mills, H. (1956). Africa Mud Fish Clarias lazera IBADAN Unv. Press.

Olafsdottir, G., Martindottir, E., Oehlenschlager, J., Dalgaard, P., Jensen, B., Undeland, I., Mackie, I. M., Heneman, G., Nielsen, J. and Nielsen, H. (1997). Method to evaluate fish freshness in research and industry. Trends Food Science Technology, 81: 258 265. .

SAS. (1988). SAS User's Guide: Statistics. Cary, N.C.: SAS Institute Inc. 956 p.

Shewan, J. (1977). The bacteriology of fish and spoilage fish and biochemical changes induced by bacterial action. In: proceeding of conference on handling, processing, and marketing of topical fish, pp. $51-66$. Ondon, Tropical Product Institute.

Sikorski, Z.E. (1990). Seafood: Resources, Nutritional Composition, and Preservation. Boca Raton, Fla.: CRC Press Inc. p 248.

Sivertsvik, M., W. K. Jeksrud and J. T. Rosnes, (2002). A review of modified atmosphere packaging of fish and fishery products - significance of microbial growth, activities safety. Intl. J. food Sci. Techol., 37: 107 127.

SSMO (SDS 357). Aerobic plate count (APC) for fresh or frozen fish and its products. Fishing Products and Seafoods. Sudanese Standards and Metrology or Organization.

Stile, M. E., (1991). Scientific principles of controlled/ modified Atmosphere packaging. In: Modified Atmosphere Packaging of Food. Oorikul B. and M. E. stiles (eds.), Ellis Harwood, London, pp: $18-25$.

Surendran, P. K., J. Joseph, A. V., Shenoy, P. A., Perigreen, K. M. and Gopakumar, K. (1989). Studies on spoilage of commercially imported tropical fishes under iced stored. Fish Res., 7: 1 - 9.

Thai Agricultural Commodity and Food Standard (TACFS). 2004. Tilapia. National Bureau of Agricultural Commodity and Food Standards (ACFS). TACFS 7001 - 2004. 8P.

Thurman, H. V. and Webber, H. H. (1984). Marine biology charles, E. Merrill Publishing C. A. Bell and Howell co. Columbus, Ohio U. S. A.

Turantas, F. (2000). Mikrobiyolojik kriterler. In Gida Mikrobiyolojisi (A. Unluturk and Turatas, F. eds.). Mengi Tan Bansimevi, Izmir, Turkey, pp. 517 - 549. 